\title{
Syntrophobacter fumaroxidans sp. nov., a syntrophic propionate-degrading sulfate- reducing bacterium
}

\author{
Hermie J. M. Harmsen, Bernardina L. M. Van Kuijk, Caroline M. Plugge, \\ Antoon D. L. Akkermans, Willem M. De Vos and Alfons J. M. Stams
}

\author{
Author for correspondence: Alfons J. M. Stams. Tel: +31 317482105 . Fax: +31317483829. \\ e-mail: fons.stams@algemeen.micr.wau.nl
}

Laboratory of

Microbiology,

Wageningen Agricultural

University, Hesselink van

Suchtelenweg 4, 6703 CT

Wageningen,

The Netherlands

\begin{abstract}
A syntrophic propionate-oxidizing bacterium, strain MPOB', was isolated from a culture enriched from anaerobic granular sludge. It oxidized propionate syntrophically in co-culture with the hydrogen- and formate-utilizing Methanospirillum hungateii, and was able to oxidize propionate and other organic compounds in pure culture with sulfate or fumarate as the electron acceptor. Additionally, it fermented fumarate. 165 rRNA sequence analysis revealed a relationship with Syntrophobacter wolinii and Syntrophobacter pfennigii. The G+C content of its DNA was $60.6 \mathrm{~mol} \%$, which is in the same range as that of other Syntrophobacter species. DNA-DNA hybridization studies showed less than $26 \%$ hybridization among the different genomes of Syntrophobacter species and strain MPOB'. This justifies the assignment of strain MPOB' to the genus Syntrophobacter as a new species. The name Syntrophobacter fumaroxidans is proposed; strain MPOB' (= DSM 10017') is the type strain.
\end{abstract}

Keywords: Syntrophobacter fumaroxidans sp. nov., syntrophy, propionate oxidation

\section{INTRODUCTION}

For a long time, Syntrophobacter wolinii was the only described bacterium which could oxidize propionate syntrophically in co-culture with the hydrogen-consuming Desulfovibrio G11 (1). Several methanogenic syntrophic co-cultures were enriched, but obtaining defined co-cultures remained difficult. S. wolinii was only recently obtained in pure culture, and found to be able to grow on pyruvate or on propionate and sulfate (17). Two related syntrophic propionate-oxidizing bacteria, Syntrophobacter pfennigii, previously known as KOPROP1, and strain HP1.1 were isolated with propionate and sulfate $(18,19)$.

A mesophilic bacterium (strain $\mathrm{MPOB}^{\mathrm{T}}$ ) enriched by us on propionate was able to ferment fumarate to succinate and carbon dioxide without a syntrophic partner (12). This strain could oxidize propionate by using fumarate or sulfate as electron acceptors $(12,15)$. Similar to $S$. wolinii, strain $\mathrm{MPOB}^{\mathrm{T}}$ oxidized propionate via the methylmalonyl-CoA pathway, but in contrast to $S$. wolinii, strain $\mathrm{MPOB}^{\mathrm{T}}$ activates pro-

The accession number for the sequence reported in this paper is $\times 82874$. pionate by the use of HS-CoA transferase (11). 16S rRNA sequence analysis of $S$. wolinii, $S$. pfennigii, strain HP1.1 and strain MPOB $^{\mathrm{T}}$ revealed that these syntrophic bacteria are closely related and belong to the delta subclass of Proteobacteria (3, 4, 19). Remarkably, it was observed that another bacterium was related to this group: Desulforhabdus amnigenus, a sulfate-reducing bacterium which is not able to grow syntrophically on propionate (10).

Recently, we obtained a pure culture of strain $\mathrm{MPOB}^{\mathrm{T}}$. Its morphological and physiological characterization are presented here, and its taxonomic position within the genus Syntrophobacter is discussed.

\section{METHODS}

Bacterial strains, cultivation and isolation procedures. Strain MPOB $^{\mathrm{T}}$ originated from a propionate-degrading culture enriched from granular sludge of an upflow anaerobic sludge blanket reactor treating wastewater from a sugar refinery (12). Syntrophobacter wolinii (DSM 2805) and Desulfobulbus propionicus (DSM 2505) were obtained from the DSMZ (Deutsche Sammlung von Mikroorganismen und, Zellkulturen Braunschweig, Germany). Syntrophobacter pfennigii was kindly provided by B. Schink (University of 
Table 1. Organic compounds tested as electron donors and carbon sources for strain MPOB $^{\top}$

Substrate concentrations are given in parentheses in $\mathrm{mM}$ except where stated. $\mathrm{CO}_{2}$ and $\mathrm{NH}_{4}^{+}$ were not measured but their formation was assumed from expected stoichiometries of conversion.

\begin{tabular}{|c|c|}
\hline Substrate used: & Products \\
\hline \multicolumn{2}{|l|}{ In co-culture with $M$. hungateii } \\
\hline Propionate $(20)$ & Acetate, $\mathrm{CO}_{2}$ and methane \\
\hline \multicolumn{2}{|l|}{ In pure culture } \\
\hline Propionate $(20)+$ fumarate $(20)$ & Acetate, $\mathrm{CO}_{2}$ and succinate \\
\hline Fumarate $(20)$ & Succinate and $\mathrm{CO}_{2}$ \\
\hline Malate $(20)$ & Succinate and $\mathrm{CO}_{2}$ \\
\hline Aspartate & Succinate, $\mathrm{NH}_{4}^{+}$and $\mathrm{CO}_{2}$ \\
\hline $\mathrm{H}_{2}(80 \%)+$ fumarate $(20)$ & Succinate \\
\hline Formate $(20)+$ fumarate $(20)$ & Succinate and $\mathrm{CO}_{2}$ \\
\hline Pyruvate $(20)$ & Acetate, succinate and $\mathrm{CO}_{2}$ \\
\hline \multicolumn{2}{|l|}{ In pure culture in presence of $20 \mathrm{mM}$ sulfate } \\
\hline Propionate $(20)$ & Acetate and $\mathrm{CO}_{2}$ \\
\hline Formate $(20)$ & $\mathrm{CO}_{2}$ \\
\hline Succinate $(20)$ & $\mathrm{CO}_{2}^{2}$ \\
\hline Hydrogen $(80 \%)$ & poor growth \\
\hline \multicolumn{2}{|l|}{ Not utilized in presence of $20 \mathrm{mM}$ sulfate } \\
\hline $\begin{array}{l}\text { Butyrate }(10) \text {, isobutyrate }(10) \text {, acetate }(20) \text {, citrate } \\
(10) \text {, lactate }(20) \text {, butanol }(10) \text {, propanol }(20) \text {, ethanol } \\
(20) \text {, methanol }(10) \text {, glucose }(20) \text {, fructose }(10), \\
\text { xylose }(10) \text {, glutamate }(20)\end{array}$ & - \\
\hline
\end{tabular}

Konstanz, Germany). Desulforhabdus amnigenus was provided by $S$. Oude Elferink (Wageningen Agricultural University, The Netherlands).

A previously described bicarbonate-buffered medium was used for isolation and cultivation (12). For isolation of strain MPOB $^{\mathrm{T}}$ the roll-tube-dilution method (5) and direct dilution series in liquid media with fumarate as carbon and energy sources were used. Purity was checked by growth in Wilkins-Chalgren anaerobe broth (Oxoid), and in media containing $1 \%$ yeast extract and $20 \mathrm{mM}$ glucose, and by microscopy.

Phylogeny and DNA analysis. Phylogenetic analysis of the strain has been described previously $(4,10)$. The nucleotide sequence of strain MPOB $^{\mathrm{T}}$ was aligned using the Dedicated Comparative Sequence Editor version 2.60 alignment program with other $16 \mathrm{~S}$ rRNA sequences derived from the NCBI collection and the Antwerp RRNA database. The sequence of strain HP1.1 was kindly provided by G. Zellner (Wageningen Agricultural University). Only nucleotides that could be unambiguously aligned were taken into account. A phylogenetic tree based on the neighbour-joining method was constructed from a distance matrix according to the two-parameter model of Kimura, as implemented in the TREECON for Windows software package (14).

DNA hybridizations were performed by filter hybridization according to Johnson et al. (6). Modifications of this method for DNA labelling and hybridization conditions have been described previously (8). The final stringent washing was done at $65^{\circ} \mathrm{C}$ in $0.03 \mathrm{M} \mathrm{NaCl}, 0.003 \mathrm{M}$ sodium citrate, with $1 \%$ SDS. The percentage of binding was determined by measuring the radioactive hybridization signals relative to that found in the homologous hybridizations. The $\mathrm{G}+\mathrm{C}$ content of the DNA was analysed at the DSMZ using standard methods $(9,13,16)$.

Chemical analyses. All compounds except amino acids were measured by GC and HPLC as described previously (12). Amino acids were measured as described previously (7). The presence of cytochromes was analysed by recording airoxidized versus dithionite-reduced spectra of cell-free extracts and membrane fractions. The types of quinones were analysed at the DSMZ by HPLC.

\section{RESULTS AND DISCUSSION}

\section{Isolation and morphological characterization}

The origin and enrichment of the syntrophic propionate-oxidizing co-culture from methanogenic granular sludge has been described previously (12). The Methanospirillum sp. was removed from the coculture by continuous subculturing on malate and fumarate. However, this enrichment culture still contained a contaminating small coccoid bacterium, which could be enriched and isolated on media containing yeast extract. The roll-tube technique was applied to try to eliminate the contaminating bacteria. A culture containing about $10^{8}$ cells $\mathrm{ml}^{-1}$ was diluted in anaerobic roll tubes with fumarate as the carbon source; this resulted after two months in the formation of yellowish colonies of about $2 \mathrm{~mm}$ diameter in the $10^{-4}$ and $10^{-5}$ dilutions. However, when these colonies were cultured in liquid medium with fumarate as substrate and $0.05 \%$ yeast extract, contaminating 


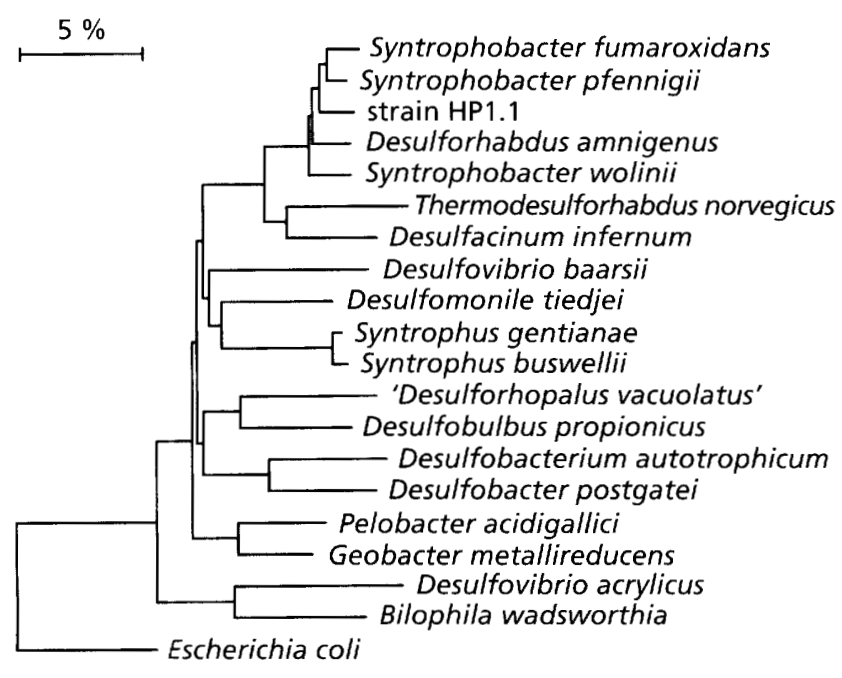

Fig. 1. Phylogenetic tree based on rRNA sequence comparisons of $\mathrm{MPOB}^{\top}$ with members of the delta subclass of Proteobacteria. The tree is based on a distance analysis using only those nucleotides that could be unambiguously aligned, and was constructed via the neighbour-joining method as implemented in TREECON for Windows (14). The scale bar represents $5 \%$ estimated sequence divergence. The accession numbers of the $16 \mathrm{~S}$ rRNA sequences used are: Syntrophobacter fumaroxidans, X82874; Syntrophobacter wolinii, X70906; Syntrophobacter pfennigii, X82875; HP1.1, X94911; Desulforhabdus amnigenus X83274; Thermodesulforhabdus norvegicus, U25627; Desulfacinum infernum, L27426; Desulfovibrio baarsii, M34403; Desulfomonile tiedjei, M26635; Syntrophus gentianae, X85132; Syntrophus buswellii, X85131; 'Desulforhopalus vacuolatus', L42613; Desulfobulbus propionicus, M34410; Desulfobacterium autotrophicum, M34409; Desulfobacter postgatei, M26633; Pelobacter acidigallici, X77216; Geobacter metallireducens, L07834; Desulfovibrio acrylicus, U32578; Bilophila wadsworthia, L35148.

bacteria were still found. Therefore, dilution series of this liquid enrichment were made, with fumarate as substrate and $0.05 \%$ yeast extract, to simultaneously purify the bacterium and check for growth of the contaminant. Growth was observed up to a dilution of $10^{-8}$. This dilution appeared to be free of the contaminating coccoid bacterium. This culture (strain $\mathrm{MPOB}^{\mathrm{T}}$ ) consisted only of the Gram-negative, non motile, rod-shaped bacterium $(1 \cdot 1-1.6 \mu \mathrm{m}$ wide and $1 \cdot 8-2 \cdot 5 \mu \mathrm{m}$ long) described previously (12).

\section{Physiological characterization}

Strain $\mathrm{MPOB}^{\mathrm{T}}$ grew on fumarate between 20 and $40^{\circ} \mathrm{C}$ with an optimum at $37^{\circ} \mathrm{C}$. The $\mathrm{pH}$ range was $\mathrm{pH} 6.0-8.0$ with optimum growth around $\mathrm{pH} 7$. Addition of $0.05 \%$ yeast extract was not necessary, but it stimulated growth. In co-culture with $M$. hungateii, strain $\mathrm{MPOB}^{\mathrm{T}}$ had a growth rate on propionate of approximately $0.17 \mathrm{~d}^{-1}$. In pure culture, lower growth rates were observed; $0.09 \mathrm{~d}^{-1}$ during fermentative growth on fumarate and $0.024 \mathrm{~d}^{-1}$ during growth on propionate and sulfate (15). Both $c$ - and $b$-type cytochromes as well as the menaquinones MK-6 and MK-7 were present in fumarate-grown cells.
Table 2. Percentage of DNA-DNA hybridization of $\mathrm{MPOB}^{\top}$ (1), Syntrophobacter wolinii (2), Syntrophobacter pfennigii (3), Desulforhabdus amnigenus (4) and Desulfobulbus propionicus (5)

DNA samples from strains mentioned in the left column were bound to the filter and hybridized with DNA samples from strains given in the top row.

\begin{tabular}{|cccccc|}
\hline & $\mathbf{1}$ & $\mathbf{2}$ & $\mathbf{3}$ & $\mathbf{4}$ & $\mathbf{5}$ \\
\hline $\mathbf{1}$ & 100 & $9 \cdot 4$ & $16 \cdot 4$ & $24 \cdot 7$ & $11 \cdot 4$ \\
$\mathbf{2}$ & $23 \cdot 2$ & 100 & $16 \cdot 3$ & $26 \cdot 0$ & $8 \cdot 8$ \\
$\mathbf{3}$ & $19 \cdot 8$ & $5 \cdot 0$ & 100 & $13 \cdot 0$ & $6 \cdot 1$ \\
$\mathbf{4}$ & $14 \cdot 4$ & $2 \cdot 3$ & $8 \cdot 2$ & 100 & $4 \cdot 2$ \\
$\mathbf{5}$ & $22 \cdot 0$ & $6 \cdot 5$ & $15 \cdot 4$ & $8 \cdot 1$ & 100 \\
\hline
\end{tabular}

Strain $\mathrm{MPOB}^{\mathrm{T}}$ utilized propionate syntrophically in co-culture with $M$. hungateii, and in pure culture using sulfate or fumarate as electron acceptors (Table 1). In these cases, it oxidized propionate stoichiometrically to acetate and $\mathrm{CO}_{2}$ with concomitant production of methane, sulfide or succinate, respectively. Thiosulfate could also serve as an electron acceptor, but nitrate was not utilized. Strain MPOB ${ }^{\mathrm{T}}$ fermented fumarate to succinate and $\mathrm{CO}_{2}$, and reduced fumarate to succinate with hydrogen or formate as the electron donor (12). In addition, strain $\mathrm{MPOB}^{\mathrm{T}}$ grew on some organic compounds (Table 1).

During the course of the experiments, it was observed that strain $\mathrm{MPOB}^{\mathrm{T}}$ grew better when a batch of $\mathrm{FeCl}_{2}$ was used in which the iron was partially oxidized, as indicated by the brownish colour. However, when the trace elements solution was added after autoclaving, this difference was not observed.

\section{Taxonomy}

The 16S rRNA sequence of strain $\mathrm{MPOB}^{\mathrm{T}}$ was analysed, and compared with the sequences of $S$. wolinii and S. pfennigii (4). Using the 16S rRNA sequence data obtained previously, a new phylogenetic tree was constructed that includes the syntrophic propionate-oxidizing bacteria $S$. wolinii, $S$. pfennigii, strain HP1.1, strain MPOB ${ }^{\mathrm{T}}$ and the sulfate-reducing bacterium Desulforhabdus amnigenus, and members of the delta subclass of Proteobacteria $(3,4,10,19)$ (Fig. 1). This tree clearly shows that the syntrophic propionate-oxidizing bacteria form one cluster with Desulforhabdus amnigenus and belong, according to the grouping of Devereux et al. (2), to group 7 of the delta subclass of Proteobacteria. This is a phylogenetically distinct group from the line of completeoxidizing sulfate-reducing bacteria. To investigate this relationship at the species level, DNA-DNA hybridizations were performed. Labelled chromosomal DNA of each of the four strains, and Desulfobulbus propionicus as an unrelated strain, was hybridized with membrane-fixed chromosomal DNA 
Table 3. Comparison of different syntrophic propionate-oxidizing bacteria

\begin{tabular}{|lcccc|}
\hline ND, Not determined. & MPOB & S. wolinii & S. pfennigii & HP1.1 \\
\hline Morphology & Lemon-shaped & Straight rod & Straight rod & Lemon-shaped \\
Size* & & & & \\
width $(\mu \mathrm{m})$ & $1 \cdot 1-1 \cdot 6$ & $0 \cdot 7-0 \cdot 9$ & $1 \cdot 0-1 \cdot 2$ & $1 \cdot 0-1 \cdot 2$ \\
length $(\mu \mathrm{m})$ & $1 \cdot 8-2 \cdot 5$ & $1 \cdot 5-2 \cdot 3$ & $2 \cdot 2-3 \cdot 0$ & $1 \cdot 4-2 \cdot 4$ \\
Motility & No & No & Yes & No \\
Gram stain & Negative & Negative & Negative & Negative \\
Gas vacuoles & No & No & Yes & No \\
SO reduction & Yes & Yes & Yes & Yes \\
Optimal temp. $\left({ }^{\circ} \mathrm{C}\right)$ & 37 & ND & 37 & 40 \\
G+C content $(\mathrm{mol} \%)$ & $60 \cdot 6$ & ND & $57 \cdot 3$ & $56 \cdot 7$ \\
References & This study & 1,17 & 18 & 19 \\
\hline
\end{tabular}

* In a syntrophic propionate-oxidizing co-culture.

of the same strains (Table 2). The homology observed between the different strains was always below $26 \%$, indicating that all strains belonged to different species.

Strain $\mathrm{MPOB}^{\mathrm{T}}$ resembles the syntrophic propionateoxidizing species $S$. wolinii and $S$. pfennigii by its ability to grow on propionate in co-culture with $M$. hungateii and in pure culture by sulfate reduction. A comparison of propionate-degrading strains is given in Table 3. S. wolinii can utilize fumarate and pyruvate in pure culture (17; B. L. M. van Kuijk, unpublished), and $S$. pfennigii can grow in co-culture on propanol and lactate (18). However, the utilization of aspartate, succinate and formate as substrates for sulfate reduction was not observed in these two other species. The sulfate-reducing species Desulforhabdus amnigenus cannot oxidize propionate syntrophically and does not utilize fumarate (10). The $\mathrm{G}+\mathrm{C}$ content of DNA of strain $\mathrm{MPOB}^{\mathrm{T}}$ was $60.6 \mathrm{~mol} \%$, which is slightly higher than that of other Syntrophobacter species $(18,19)$.

The morphological and physiological differences mentioned above, and the results obtained from the DNA-DNA hybridization, showed that the syntrophic strains do not belong to the same species. Therefore, it seems justified to describe strain MPOB ${ }^{\mathrm{T}}$ as a new species within the genus Syntrophobacter. We propose the name Syntrophobacter fumaroxidans $\mathrm{sp}$. nov.

\section{Description of Syntrophobacter fumaroxidans sp. nov.}

Syntrophobacter fumaroxidans (fu.mar.ox'i.dans. M. L. neut. adj. fumaricum pertaining to fumaric acid (fumarate); L. adj. oxidans oxidizing; L. adj. fumaroxidans, fumarate oxidizing).

Non motile, rod- to eye-shaped cells, $1 \cdot 1-1 \cdot 6$ by $1 \cdot 8-2.5 \mu \mathrm{m}$ in size, with round ends, single or in pairs.
Gram-negative. Endospores are not formed. The $\mathrm{G}+\mathrm{C}$ content is $60 \cdot 6 \pm 0 \cdot 2 \mathrm{~mol} \%(n=4)$. Contains $c-$ and $b$-type cytochromes, and quinones MK-6 and MK-7. Strictly anaerobic and grows syntrophically on propionate in the presence of hydrogen- and formateutilizing bacteria or methanogens (e.g. Methanospirillum hungateii). Ferments fumarate, malate, aspartate and pyruvate. Propionate, succinate and formate are oxidized coupled to sulfate-reduction. Besides sulfate, thiosulfate and fumarate can serve as electron acceptors, but nitrate is not reduced. Growth is optimal in freshwater medium, $\mathrm{pH} 7 \cdot 0-7 \cdot 6$, at $37^{\circ} \mathrm{C}$. Habitat is granular sludge from an upflow anaerobic sludge bed reactor treating sugar-beat processing wastewater. Type strain: Syntrophobacter fumaroxidans $\mathrm{MPOB}^{\mathrm{T}}\left(=\mathrm{DSM} 10017^{\mathrm{T}}\right)$.

\section{ACKNOWLEDGEMENTS}

This research was made possible by financial support of the Wageningen Agricultural University and the Foundation for Life Sciences which is subsidized by the Netherlands Organization for Scientific Research. We would like to thank M. J. E. C. Van Der Maarel for construction of the dendogram.

\section{REFERENCES}

1. Boone, D. R. \& Bryant, M. P. (1980). Propionate-degrading bacterium, Syntrophobacter wolinii sp. nov., gen. nov., from methanogenic ecosystems. Appl Environ Microbiol 40, 626-632.

2. Devereux, R., Delaney, M., Widdel, F. \& Stahl, D. A. (1989). Natural relationships among sulfate-reducing eubacteria. $J$ Bacteriol 171, 6689-6695.

3. Harmsen, H. J. M., Wullings, B., Akkermans, A. D. L., Ludwig, W. \& Stams, A. J. M. (1993). Phylogenetic analysis of Syntrophobacter wolinii reveals a relationship with sulfatereducing bacteria. Arch Microbiol 160, 238-240.

4. Harmsen, H. J. M., Kengen, H. M. P., Akkermans, A. D. L. \& Stams, A. J. M. (1995). Phylogenetic analysis of two syn- 
trophic propionate-oxidizing bacteria in enrichment cultures. Syst Appl Microbiol 18, 67-73.

5. Hungate, R. E. (1969). A roll-tube method for cultivation of strict anaerobes. Methods Microbiol 3b, 117-132.

6. Johnson, J. L. (1981). Genetic characterization. In Manual of Methods for General Microbiology, pp. 450-475. Edited by P. Gerhardt \& G. E. Murray. Washington, DC: American Society for Microbiology.

7. Kengen, S. W. M. \& Stams, A. J. M. (1994). Formation of Lalanine as a reduced end product in carbohydrate fermentation by the hyperthermophilic archaeon Pyrococcus furiosus. Arch Microbiol 161, 168-175.

8. Klijn, N., Bovie, C., Dommes, J., Hoolwerf, J. D., van der Waals, C. B., Weerkamp, A. H. \& Nieuwenhof, F. F. J. (1994). Identification of Clostridium tyrobutyricum and related species using sugar fermentation, organic acid formation and DNA probes based on specific 16S rRNA sequences. Syst Appl Microbiol 17, 249-256.

9. Mesbah, M., Premachandran, U. \& Whitman, B. W. (1989). Precise measurement of the $\mathrm{G}+\mathrm{C}$ content of deoxyribonucleic acid by high-performance liquid chromatography. Int J Syst Bacteriol 39, 159-167.

10. Oude Elferink, S. J. W. H., Maas, R. N., Harmsen, H. J. M. \& Stams, A. J. M. (1995). Desulforhabdus amnigenus gen. nov., sp. nov., a sulfate reducer isolated from anaerobic granular sludge Arch Microbiol 164, 119-124.

11. Plugge, C. M., Dijkema, C. \& Stams, A. J. M. (1993). AcetylCoA cleavage pathway in a syntrophic propionate oxidizing bacterium growing on fumarate in the absence of methanogens. FEMS Microbiol Lett 110, 71-76.
12. Stams, A. J. M., van Dijk, J. B., Dijkema, C. \& Plugge, C. M. (1993). Growth of syntrophic propionate-oxidizing bacteria with fumarate in the absence of methanogenic bacteria. Appl Environ Microbiol 59, 1114-1119.

13. Tamaoka, J. \& Komagata, J. (1984). Determination of DNA base composition by reversed-phase high-performance liquid chromatography. FEMS Microbiol Lett 25, 125-128.

14. Van de Peer, Y. \& de Wachter, R. (1994). TREECON for Windows: a software package for the construction and drawing of evolutionary trees for the Microsoft Windows environment. Comput Appl Biosci 10, 569-570.

15. Van Kuijk, B. L. M. \& Stams, A. J. M. (1995). Sulfate reduction by a syntrophic propionate-oxidizing bacterium. Antonie Leeuwenhoek 68, 293-296.

16. Visuvanathan, S., Moss, M. T., Stanford, J. L., Hermon-Taylor, J. \& McFadden, J. J. (1989). Simple enzymic method for isolation of DNA from diverse bacteria. $J$ Microbiol Methods 10, 59-64.

17. Wallrabenstein, C., Hauschild, E. \& Schink, B. (1994). Pure culture and cytological properties of Syntrophobacter wolinii. FEMS Microbiol Lett 123, 249-254.

18. Wallrabenstein, C., Hauschild, E. \& Schink, B. (1995). Syntrophobacter pfennigii $\mathrm{sp}$, nov., new syntrophically propionateoxidizing anaerobe growing in pure culture with propionate and sulfate. Arch Microbiol 164, 346-352.

19. Zellner, G., Busmann, A., Rainey, F. A. \& Diekmann, H. (1996). A syntrophic propionate-oxidizing, sulfate-reducing bacterium from a fluidized bed reactor. Syst Appl Microbiol 19, $414-420$ 
